\title{
CLASSROOM MANAGEMENT, ACADEMIC LOCUS OF CONTROL, AND COMMUNICATION COMPETENCE: A STRUCTURAL EQUATION MODEL ON LANGUAGE LEARNING ATTITUDES
}

\author{
Gemma Landerio-Reyes ${ }^{1}$, Marilou Y. Limpot ${ }^{2}$ \\ ${ }^{I}$ Doctor of Philosophy in Filipino, University of Mindanao, Davao City, Philippines \\ ${ }^{2}$ Doctor of Education, University of Mindanao, Davao City, Philippines
}

Article DOI: https://doi.org/10.36713/epra9578

DOI No: 10.36713/epra9578

\begin{abstract}
This research aimed to establish the best-fit structural model for learning the Filipino language. Specifically, the study intended to determine the relationship between the exogenous variables: classroom management, academic locus of control, communication competence, and the endogenous variable: language learning attitudes. Four hundred respondents, chosen through stratified random sampling, took the survey. The mean, Pearson $r$, regression analysis, and structural equation modeling (SEM) analyzed the data. These are the results: both exogenous and endogenous variables have high levels, the relationship between classroom management, academic locus of control, and language learning attitudes are moderate, positive, and significant. However, communication competence did not substantially affect language learning attitudes. Of the three exogenous variables, the academic locus of control has the most influence on language learning attitudes. The structural equation modeling (SEM) result showed all three exogenous variables as predictors of language learning attitudes, with their manifest variables. For example, classroom management manifested by specific teaching strategy and planning and support; academic locus of control demonstrated by being hopeful, being positive, and better planning; communication competence exemplified by communicating with acquaintances and friends. The findings of this study have insinuations for the overall teaching and learning environment.
\end{abstract}

KEYWORDS: structural equation modeling, classroom management, academic locus of control, communication competence, language learning attitudes

\section{INTRODUCTION}

Research has shown that language learning attitudes are essential elements in attaining success in the field of academics and in learning a language [1]; [2]; [3]; [4]; [5]. However, nowadays, students lack positive attitudes towards language learning [6]; [7]. For example, in the Philippines, students' interest in learning the Filipino language is diminishing [8]. Researchers of second language learning have observed the same scenario resulting in a continuing discussion of the issue in different seminars and conferences [9].

For decades, researchers have focused on attitudes as the first element in language learning [10]; [11]; [12]; [13]; [14]; [15]. Some second language learning researchers investigate this topic using models [16]; [17]. While language learning attitudes are the core of the investigation, other researchers also investigated other language-learning correlations [18]; [19]; [20]; [21]. For example, [22] found a significant relationship between classroom management and attitudes in learning a topic. The [23] also acknowledged the same and insisted that classroom management could change the way students view learning. [24] also found that learning attitudes have a more significant impact on second language learning.

Long before, [25] already discovered a significant relationship between academic locus of control and language learning attitudes. Trice observed that learning could come easy when students find their source of motivation, especially with their teachers' close guidance and monitoring. [26] confirmed Trice's findings, pounding on the essentiality of locus of control not only in language learning but in all aspects of life, even in health [27] and work [28]. According to [29], a person with a high-level locus of control is happier than those with low ones.

On the other hand, research also showed a significant correlation between communication competence and language learning attitudes. For instance, researchers have reported the vital role of communication competence in shaping positive attitudes towards second language learning [30]; [31]; [32]; [33]. Likewise, [34] claimed that connecting with friends and acquaintances motivates learning a foreign language and culture. 
Moreover, despite all these researches on classroom management, academic locus of control, communication competence, and language learning attitudes, the researcher has not come across a study that delves into structural equation modeling using these variables in the local setting. Thus,

\section{OBJECTIVES}

This study pursued to create the best fit model for language learning attitudes using classroom management, academic locus of control, and communication competence as

\section{METHODS}

This study is a quantitative research that used Structural Equation Modeling (SEM) to establish the best fit model for language learning attitudes. SEM is a multivariate statistic used to estimate a complex relationship between the latent and manifest variables [35]; [36]. This study also used a Pearson's $r$ in determining the linear correlation between the variables through numerical data [37]. The regression analysis helped establish the predictors of language learning attitudes [38]. acknowledging a research gap on this approach. This study would benefit the teachers and students and the entire field of education, especially in language learning.

exogenous variables, and language learning attitudes as the endogenous variable.

Moreover, this research used stratified random sampling to select enough representation for specific population characteristics [39]. For example, since four colleges were offering a degree in education major in the Filipino language, each school had 100 representatives, making 400 respondents in all.

\section{RESULTS AND DISCUSSION}

Table 1

Level of Classroom Management

\begin{tabular}{|c|c|c|c|}
\hline Indicators & SD & Mean & Descriptive Level \\
\hline Managing Attitudes inside the Classroom & 0.83 & 3.92 & High \\
\hline Specific Teaching Strategy & 0.40 & 3.82 & High \\
\hline Cooperating with Parents & 0.53 & 3.94 & High \\
\hline Planning and Support & 0.63 & 3.67 & High \\
\hline Overall & 0.43 & 3.84 & High \\
\hline
\end{tabular}

Table 1 shows the data on classroom management. The overall mean score is 3.84 , with a standard deviation of 0.43 . The result means that the respondents agreed to have observed all these indicators inside the classroom often and decided that classroom management is necessary for learning a language. The standard deviation also suggested that the respondents have more or less the same answer to each item in the survey.

Classroom management is vital in shaping the students' attitudes in learning whatever language. Foremost, managing a classroom is essential in setting the learning atmosphere and the condition of the learners in the school [40]. [41] observed how the teacher manages the classroom affects the whole learning environment. Necessarily, the students' attitudes result from what is happening inside the classroom. The better the classroom management, the better the outcome [42]; [43]; [44]; [45]. 
Table 2

Level of Academic Locus of Control

\begin{tabular}{lccc}
\hline \multicolumn{1}{c}{ Indicators } & SD & Mean & Descriptive Level \\
\hline Being Hopeful & 0.60 & 4.07 & High \\
Having Focus & 0.70 & 3.93 & High \\
Being Optimistic/Positive & 0.50 & 4.00 & High \\
Better Planning & 0.57 & 4.04 & High \\
\multicolumn{1}{c}{ Overall } & $\mathbf{0 . 5 2}$ & $\mathbf{4 . 0 1}$ & High \\
\hline
\end{tabular}

Table 2 shows the overall high-level rating for the academic locus of control $(\mathrm{M}=4.01, \mathrm{SD}=0.52)$. Again, the result means that the students have high hopes, focus, optimism, and better planning. Research has proven that having a high locus of control has to do with academic success [46]; [47]; [48]; [49]. Foremost, hope is a dynamo that drives a person towards his dreams, and having high hopes makes him wade his way through amidst obstacles[50]; [51]. Moreover, no distraction and negative influences can sway a student whose eyes are focused on learning and his ambition [52]. But first, that student must have a solid academic locus of control to sharpen his positive thinking and wield his planning skills [53]; [54]. A strong locus of control is needed not only in the field of education but in all aspects of human life because it is where a person draws his inner strength [55]; [56]; [57].

Table 3

Level of Communication Competence

\begin{tabular}{lccc}
\hline \multicolumn{1}{c}{ Indicators } & SD & Mean & Descriptive Level \\
\hline Communicating with Strangers & 0.62 & 4.10 & High \\
Communicating with Acquaintances & 0.67 & 4.13 & High \\
Communicating with Friends & 0.62 & 4.15 & High \\
\multicolumn{1}{c}{ Overall } & $\mathbf{0 . 4 7}$ & $\mathbf{4 . 1 3}$ & High \\
\hline
\end{tabular}

Table 3 displays the mean results of the level of communication competence. Overall, the communication competence is high $(\mathrm{M}=4.13$; $\mathrm{SD}=0.47)$, with all indicators having equally high-level mean ratings. These ratings mean that the respondents were amenable to the necessity of often communicating with strangers, acquaintances, and friends in learning a language. The result herein conforms to the ideas of some authors that these communication avenues could add to competence in communication [58]; [59]; [60].

Nowadays, communication between people is more accessible because of communication technology infrastructures. For example, people use text messaging, online chat, video calls, blogs, vlogs, at social networking [61] to communicate with friends, acquaintances, or strangers. In addition, these communication infrastructures help language students learn other languages quickly [62]; [63].

Apart from technology, the teachers also influence how students learn a language in the classroom setting [64]. For example, communication competence has four aspects: reading, writing, listening, and speaking. The teacher can facilitate these by managing communication inside the classroom [65]. [66] claimed that how the teacher works on communication in the class determines the transfer of language learning among students.

Table 4

Level of Language Learning Attitudes

\begin{tabular}{lcccc}
\hline & Indicators & SD & Mean & Descriptive Level \\
\hline Attitudes towards Learning the Filipino Language & 0.73 & 3.79 & High \\
Integrative Orientation & & 0.67 & 3.86 & High \\
Strength of Motivation & Overall & 0.58 & 4.03 & High \\
& & $\mathbf{0 . 5 0}$ & $\mathbf{3 . 9 0}$ & High \\
\hline
\end{tabular}


Table 4 displays the language learning attitudes of students manifested by attitudes towards learning the Filipino language, integrative orientation, and strength of motivation. Again, all mean scores are high, which means respondents often observed these indicators among language students.

The review of related literature stressed that having higher attitudes towards language learning is crucial as it increases students' interest in learning the language [67]. However, [68] discovered that men and women learn differently. Women have a higher level of positive attitudes towards language learning than their male counterparts, implying that women quickly learn a new language.

There are some advantages to learning a new language. For example, [69] explained that a person knowledgeable of another language is more tolerant and understanding of other people. In addition, he can have an opportunity to find work abroad. The [70] echoed the same idea, saying that in the $21^{\text {st }}$ century, where globalization connects communities and culture, positive attitudes towards learning a language are requisite. Teachers can help students in this aspect [71]; [72]; [73].

Table 5

Relationship between the Exogenous Variables and Language Learning Attitudes

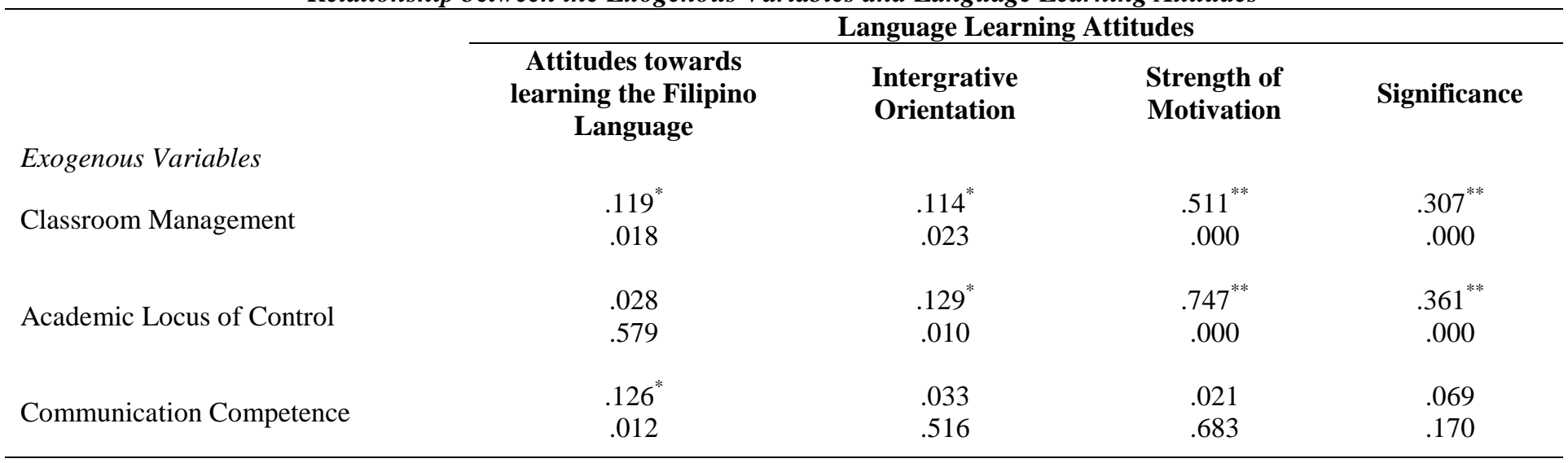

Sig. at the $p<0.01 * * \& p<0.05 *$ level $(2$-tailed $)$

The correlation test displayed in Table 5 revealed a not significant relationship between communication competence (CC) and language learning attitudes, which means that the increase in the level of CC will not increase the LLA. However, the correlation test with the other variables was significant at $\mathrm{p}<0.5$. Therefore, classroom management $(\mathrm{CM})$ and language learning attitudes (LLA) have a significant relationship, and academic locus of control (ALC) and language learning attitudes (LLA) also. Supplementarily, the association of the variables is linear, which means that as the CM and ALC increase, LLA also tends to increase.

The result is harmonious with [74] research finding that classroom management and language learning attitudes are correlated. They added that language learning anxiety decreased by how well the teacher managed the classroom. This requires the management expertise of teachers for the entire learning environment. [75] noticed that students display different interest levels; thus, demanding various strategies in dealing with the problem. Some authors have suggested that teachers do action research regarding the issue of learning interest among students to appropriately respond to it and achieve a worthwhile learning environment [76]; [77]; [78].

Likewise, researchers have reported a significant relationship between academic locus of control and language learning attitudes regardless of culture and position in life [50; [79]; [80]. 
Table 7

Influence of the Exogenous Variables on Language Learning Attitudes

Exogenous Variables

Constant

Classroom Management

Academic Locus of Control

Communication Competence

$\begin{array}{cc}\mathrm{R} & .393 \\ \mathrm{R}^{2} & .154 \\ \Delta \mathrm{R} & .148 \\ \mathrm{~F} & 24.111 \\ \rho & .000\end{array}$

Table 7 displays the result of the regression analysis of data. Table 7 revealed a combined influence of the exogenous variables on language learning attitudes at 15.4 percent. Although the impact is small, it is significant, which means that classroom management, academic locus of control, and communication competence affect students' attitudes in learning the Filipino language. Furthermore, each exogenous variable showed its predictive capability even in their singular capacities, as evidenced by their significant p-values. Additionally, the Fvalue of 24.111 with a p-value of .000 revealed the predictive power of the exogenous variables on language learning attitudes. Language learning attitudes

$\begin{array}{llcl}B & \beta & t & \text { Sig. } \\ 2.643 & & 9.378 & .000 \\ .167 & .143 & 2.457 & .014 \\ .272 & .285 & 4.876 & .000 \\ .116 & .110 & 2.373 & .018 \\ & & & \\ & & & \\ & & & \\ \end{array}$
These results are similar to some investigations on the same topics crediting classroom management as having a significant impact on language learning attitudes. For example, a better classroom could make students more comfortable, essential to learning [75]; [74]; [41]. In addition, academic locus of control impacts language learning attitudes owing to its positive driving force towards goal achievement [52]; [53]; [81]. Finally, communication competence makes learning a new language easier [59]; [66]; [82]. The results support the anchor theories in this study: operant conditioning by B.F. Skinner [83]; [84], locus of control [85]; [86], communication competence by [87].

Table 8

The Goodness of Fit with the Comparative Criterion Indices

\begin{tabular}{|c|c|c|c|c|c|c|c|c|}
\hline & $\begin{array}{c}\text { P-value } \\
(>0.05)\end{array}$ & $\begin{array}{l}\text { CMIN / DF } \\
(0<\text { value }<2)\end{array}$ & $\begin{array}{c}\text { NFI } \\
(>0.95)\end{array}$ & $\begin{array}{c}\text { TLI } \\
(>0.95)\end{array}$ & $\begin{array}{c}\text { CFI } \\
(>0.95)\end{array}$ & $\begin{array}{c}\text { GFI } \\
(>0.95)\end{array}$ & $\begin{array}{c}\text { RMSEA } \\
(<0.05)\end{array}$ & $\begin{array}{l}\text { P-close } \\
(>0.05)\end{array}$ \\
\hline $\begin{array}{l}\text { Best-Fit } \\
\text { Model of } \\
\text { Language } \\
\text { Learning } \\
\text { Attitudes }\end{array}$ & .121 & 1.351 & .984 & .992 & .996 & .985 & .030 & 909 \\
\hline Legend: & $\begin{array}{l}\text { CMIN/DF - Chi- } \\
\text { GFI }- \text { Goo } \\
\text { RMSEA }- \text { Roo }\end{array}$ & $\begin{array}{l}\text { e/Degrees of F } \\
\text { of Fit Index } \\
\text { in Square of Er }\end{array}$ & Approxim & $\begin{array}{l}\text { NFI } \\
\text { TLI } \\
\text { CFI }\end{array}$ & $\begin{array}{l}\text { ormed Fit } \\
\text { cker-Lew } \\
\text { mparativ }\end{array}$ & $\begin{array}{l}x \\
\text { dex } \\
\text { Index }\end{array}$ & & \\
\hline
\end{tabular}

Figure 1 presents the best-fit structural model for language learning attitudes based on the goodness of fit measures displayed in Table 8 . The model shows that all three exogenous variables predict language learning attitudes with some manifest variables. For example, classroom management with its manifest variables, such as specific teaching strategy (tiyak na pamamaraan sa pagtuturo-TPP), and planning and support (pagpaplano at suporta-PAS); academic locus of control with manifest variables, namely being hopeful (pagkakaroon ng pag-asa-PAG), being positive (pagiging positibo-POS), and better planning (pinabuting pagplano-PIN); communication competence with its manifest indicators, viz. communicating with an acquaintance (pakikipagkomunikasyon sa kakilalaKAK) and communicating with friends (pakikipagkomunikasyon sa kaibigan-KAI).

Similar studies have found that classroom management helped students participate in language learning activities [22]; [42]. In addition, academic locus of control helped students find their source of motivation in learning a language [46]; [47]. Finally, communication competence helped students read, write, listen, and speak a new language with their friends and acquaintances [58]; [62]; [63]; [60]. 


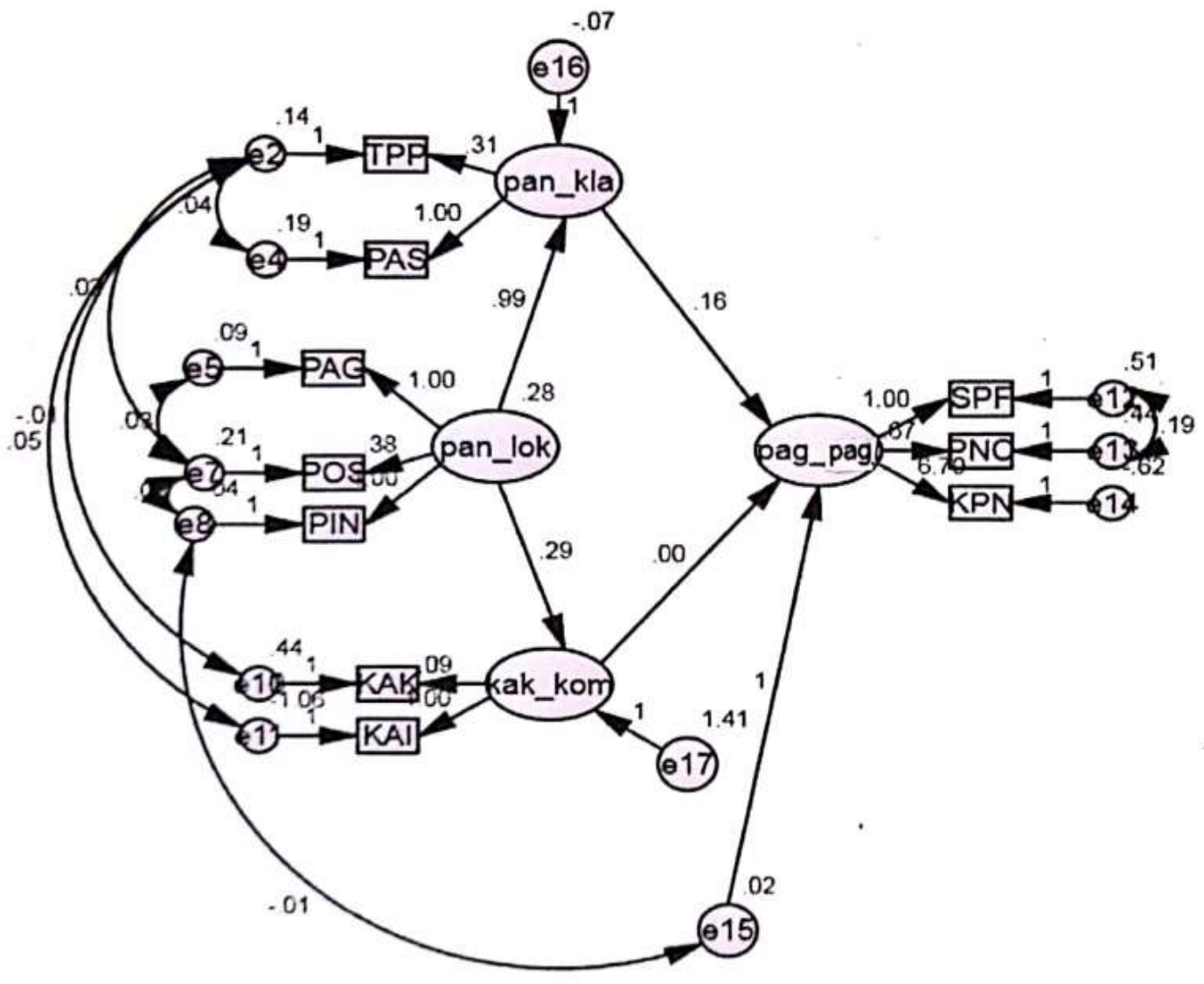

Legend

$$
\begin{aligned}
& \text { Pan_kla - Classroom Management } \\
& \text { (Pangangasiwang Pangkalsrum) } \\
& \text { TPP - Specific Teaching Strategy (Tiyak na } \\
& \text { Pamamaraan sa Pagtuturo) } \\
& \text { PAS - Planning and Support (Pagpaplano at }
\end{aligned}
$$

$\begin{array}{ll}\text { Pan_Lok } & \begin{array}{l}\text { - Academinc Locus of Control (Pang- } \\ \text { akademikong Lokus ng Kontrol) }\end{array} \\ \text { PAG } & \begin{array}{c}\text { - } \\ \text { Being Hopeful (Pagkakaroon ng Pag- } \\ \text { asa) }\end{array} \\ \text { POS } & - \text { Being Positive (Pagiging Positibo) } \\ \text { PIN } & -\begin{array}{l}\text { Better Planning (Pinabuting } \\ \text { Pagplano) }\end{array}\end{array}$

Figure 1

\section{Best-Fit Structural Model on Language learning attitudes}
Kak_Kom - Communication Competence (Kakayahan sa Komunikasyon)
KAK - Communicating with an Acquaintance (Pakikipagkomunikasyon sa Kakilala)
KAI - Communicating with Friends (Pakikipagkomunikasyon sa Kaibigan)

Pag_Pag - Language Learning Attitudes (Paguugali sa Pag-aaral ng Wika)

SPF - Attitudes towards Learning the Filipino Language (Saloobin Tungo sa Pag-aaral ng Filipino)

PNO - Integrative Orientation (Painagsanib na Oryentasyon)

KPN - Strength of Motivation (Kalasan sa Pagganyak) 


\section{CONCLUSION}

The study showed that Structural Equation Modeling (SEM) is an appropriate method for this study as it successfully identified the predictors of language learning attitudes. Also, this study concluded a positive and significant relationship between classroom management and language learning attitudes and academic locus of control and language learning attitudes. Additionally, Skinner's operant conditioning theory found support from this study. The operant conditioning theory advocates that students' response (e.g., language learning attitudes) depends on the presented stimulus (e.g., classroom

\section{REFERENCES}

1. Bandura, A., \& Schunk, D. H. (1981). "Cultivating competence, self-efficacy, and intrinsic interest through proximal self-motivation." Journal of Personality and Social Psychology, 41(3), 586-598. https://doi.org/10.1037/00223514.41.3.586

2. Dörnyei, Z. (1994). "Motivation and Motivating in the Foreign Language Classroom." The Modern Language Journal, 78(3), 273-284. https://doi.org/10.1111/j.15404781.1994.tb02042.x

3. Edgar, S., Carr, S. E., Connaughton, J., \& Celenza, A. (2019). "Student motivation to learn: Is self-belief the key to transition and first-year performance in an undergraduate health professions program?" BMC Medical Education, 19(1). https://doi.org/10.1186/s12909-019-1539-5

4. He, J. B., \& Wang, Z. (2015). "Effects of learners' motivation in second language acquisition." In Energy, Environment and Green Building Materials - Proceedings of the International Conference on Energy, Environment and Green Building Materials, EEGBM 2014 (pp. 263-267). CRC Press/Balkema. https://doi.org/10.1201/b18511-55

5. Rahman, D. S., \& Sahayu, W. (2020). "How do foreign language teachers motivate students in language learning?" Studies in English Language and Education, 7(1), 181-193. https://doi.org/10.24815/siele.v7i1.15586

6. Boriri, A; \& Ishak, Y. (2020). "Relationship between Students' Learning Interests with their Language Learning Achievement." Language: Journal of Linguistics, Literature, andLanguage Education, 3(1), 38-44. https://doi.org/https://doi.org/10.5281/zenodo.3735984

7. Zulkefly, F., \& Razali, A. B. (2019). "Malaysian rural secondary school students' attitudes towards learning English as a second language." International Journal of Instruction, 12(1), 1141-1156. https://doi.org/10.29333/iji.2019.12173a

8. Villamor, J. E., Frenila, R. M., Rosales, A. K., Sitchon, C. M., Viado, R. O., \& Lim, K. A. (2014). "The study of Filipino subjects in high school students of DCA." https://www.academia.edu/6098870/

9. Ahmad I.S., Abdullah H., Ghani M.F.A., (2014). "Attitudes and motivation toward Learning the English language among students from Islamic education system background: exploring the views of teachers." Journal of Education and Learning, 8(3), 195-208.

10. Anjomshoa, L. \& Sadighi, F. (2015). "The importance of motivation in second language acquisition." International management). Likewise, this study supported Rotter's locus of control theory, which claims that individuals have the sole capacity to decide on their fate based on where they locate their motivation to act. Finally, this study supported Haberna's communication competence theory, which advances communication skills underlie logical thoughts that usher understanding between individuals. Finally, this study concluded a predictive capacity of the exogenous variables to influence students' language learning attitudes.

Journal on Studies in English Language and Literature (IJSELL, 3(2), 126-137.

11. Boo, Z., Dörnyei, Z., Ryan, S. (2015). "L2 motivation research 2005-2014: Understanding a publication surge and a changing landscape." System, 55, 145-157. doi:10.1016/j.system.2015.10.006

12. Dörnyei, Z. (2005). "The psychology of the language learner: Individual differences in second language acquisition." London, England: Lawrence Erlbaum.

13. Dörnyei, Z. \& Ryan, S. (2015). "The psychology of the language learner revisited." New York, NY: Routledge.

14. Dörnyei, Z. \& Ushioda, U. (2011). "Teaching and researching motivation." (2nd ed.). Harlow, UK: Pearson.

15. Gardner, R. C. (2001, February). "Integrative motivation: Past, present, and future." Paper presented at the Distinguished Lecturer Series, Temple University Japan, Tokyo. http://publish.uwo.ca/ gardner/docs/GardnerPublicLecture1. $p d f$

16. Adolphs, S., Clark, L., Dörnyei, Z., \& Clover, T. (2018). "Digital innovations in L2 motivation: Harnessing the power of the Ideal L2 Self." DOI: 10.1016/j.system.2018.07.014

17. Dörnyei, Z. (2019). "Towards a better understanding of the L2 Learning Experience, the Cinderella of the L2 Motivational Self System." DOI: 10.14746/ssllt.2019.9.1.2

18. Essays, UK. (2018). "Learning styles in language learning." https://www.ukessays.com/essays/linguistics/about-learningstyle.php? vref $=1$

19. Gonzales, R. \& Lopez, M. (2015). "Foreign language learning motivation questionnaire: further examination of a six-factormodel." https://www.researchgate.net/publication/269576750

20. Kulinova, O. (2015). "Vocabulary learning strategies and beliefs about vocabulary learning: a study of beginning university students of Russian in the United States." https://doi.org/10.17077/etd.nxurfdwv

21. Setiyadi, A. B. (2016). "Language Learning Strategy Questionnaire (LLSQ). A measurement to identify students learning strategies and prepare for learning English in the Indonesian context (Empirical Evidence)." GRAHA ILMU: Ruko Jambusari, Yogyakarta Indonesia

22. Arnold, P. L., \& Nunnery, J. A. (2012). "Classroom management and motivation." Encyclopedia of the Sciences of Learning, 548-552. https://doi.org/10.1007/978-1-44191428-6_1191 
23. Ministry of Education of Guyana. (2019). "The importance of planning a classroom." https://www.education.gov.gy/web/index.php/teachers/tipsfor-teaching/item/1875-the-importance-of-planning-for-theclassroom

24. Macias, D. F. (2017). "Classroom Management in Foreign Language Education: An Exploratory Review." https://files.eric.ed.gov/fulltext/EJ1165981.pdf

25. Trice, A. D. (1985) "An Academic Locus of Control Scale for college students." Perceptual \& Motor Skills, 61, 1043-1046.

26. Atibuni, D. Z., Ssenyonga, J., Olema, D. K., \& Kemeza, I. (2017). "Locus of control as a predictor of academic attitudes among university students." International Journal of Educational Policy Research and Review, 4 (6), 125-137.

27. Kesavayuth, D., Poyago-Theotoky, J., Tran, D. B., \& Zikos, V. (2020). "Locus of control, health, and healthcare utilization." Economic Modelling, 86, 227-238. https://doi.org/10.1016/j.econmod.2019.06.014

28. Cobb-Clark, D. A. (2015, December 1). "Locus of control and the labor market." IZA Journal of Labor Economics. SpringerOpen. https://doi.org/10.1186/s40172-014-0017-x

29. April, K. A., Dharani, B., \& Peters, K. (2012). "Impact of locus of control expectancy on level of well-being." Review of European Studies, 4(2), 124-137. https://doi.org/10.5539/res.v4n2p124

30. Chua, Y. P., \& Chua, Y. P. (2017). "Do computer-mediated communication skills, knowledge, and motivation mediate the relationships between personality traits and attitude toward Facebook?" Computers in Human Behavior, 70, 51-59. https://doi.org/10.1016/j.chb.2016.12.034

31. Dulksnienè, L., \& Mačianskienè, N. (2020). "Integration of Creativity-Developing Activities in Foreign Language Learning: Students' Attitude." Sustainable Multilingualism, 16(1), 65-90. https://doi.org/10.2478/sm-2020-0004

32. Macintyre, P. D., \& Charos, C. (1996). "Personality, attitudes, and affect as predictors of second language communication." Journal of Language and Social Psychology, 15(1), 3-26. https://doi.org/10.1177/0261927X960151001

33. McCroskey, J. C., \& McCroskey, L. L. . (2013). "SelfPerceived Communication Competence Scale (SPCC). Measurement Instrument Database for the Social Science." www.midss.ie

34. Mitchell, P. J., Pardinho, L. A., Yermakova-Aguiar, N. N., \& Meshkov, L. V. (2015). "Language learning and intercultural communicative competence: An action research case study of learners of Portuguese." https://doi.org/10.1016/j.sbspro.2015.08.070

35. Hooper, D., Coughlan, J., \& Mullen, M. R. (2008). "Structural equation modeling: Guidelines for determining model fit." Electronic Journal of Business Research Methods, 6(1), 53-60. https://doi.org/10.21427/D79B73

36. Igolkina, A. A., \& Meshcheryakov, G. (2020). "Semopy: A Python Package for Structural Equation Modeling." Structural Equation Modeling, 27(6), 952-963. https://doi.org/10.1080/10705511.2019.1704289

37. Apuke, O. D. (2017). "Quantitative Research Methods: A Synopsis Approach." Kuwait Chapter of Arabian Journal of Business and Management Review, 6(11), 40-47. https://doi.org/10.12816/0040336
38. Murray, L. L., \& Wilson, J. G. (2021). "Generating data sets for teaching the importance of regression analysis. "Decision Sciences Journal of Innovative Education, 19(2), 157-166.

39. Bhardwaj, P. (2019). "Types of sampling in research." Journal of the Practice of Cardiovascular Sciences, 5(3), 157.

40. Ministry of Education of Guyana. (2016). "About student attitudes on learning."

https://education.gov.gy/web/index.php/teachers/tips-forteaching/item/2192-about-student-attitudes-on-learning

41. Webster, J. (2020). "Behavior Versus Classroom Management. Finding Appropriate Strategies for Different Challenges." https://www.thoughtco.com/behavior-versusclassroom-management-3110739

42. Kapor, R. (2018). "Impact of Classroom Management on Student's Behaviors." https://www.researchgate.net/publication/323834019_Impact _of_Classroom_Management_on_Student's_Behaviors

43. Owens, J. S., Holaway, A. S., Smith, J., Evans, S. W., Himawan, L. K., Coles, E. K., Girio-Herrera, E. Mixon, C. S., Egan, T. E., \& Dawson, A. E. (2017). "Rates of Common Classroom Behavior Management Strategies and Their Associations With Challenging Student Behavior in Elementary School." https://doi.org/10.1177/1063426617712501

44. Scott, T. M. (2017). "Teaching behavior: Managing classrooms through effective instruction." Thousand Oaks, CA: Corwin.

45. Woods, R. (2019). "Classroom management plan overview." https://www.centervention.com/classroom-management-plan/

46. Choudhury, S., \& Borooah, I. (2017). "Locus of control and academic achievement of undergraduate college students of Guwahati City." International Journal of Humanities and Social Science Invention 6(4), 67-70.

47. Drago, A., Rheinheimer, D., \& Detweiler, T. (2018). "Effects of locus of control, academic self-efficacy, and tutoring on academic performance." Journal of College Student Retention: Research, Theory \& Practice 19(4), 433-51. doi.org/10.1177/1521025116645602

48. Kumaravelu, G. (2018). "Locus of control in school students and its relationship with academic achievement." Journal on school educational technology 13(4), 63-66.

49. Mohamed, A. A., Mohammed, A. M., \& Ahmed, H. A. (2018). "Relationship between locus of control and academic achievement of nursing students at Damahour University." IOSR Journal of Nursing and Health Science (IOSR-JNHS) 7(5), 01-13. DOI: 10.9790/1959-0705120113

50. Cankaya, E. M. (2016). "The role of hope and optimism on graduate students' academic performance, physical health, and well-being." https://core.ac.uk/download/pdf/147249161.pdf

51. Gallagher, M. W., Marques, S. C., \& Lopez, S. J. (2017). "Hope and the academic trajectory of college students." Springer. Journal of Happiness Studies 18(2), 341-352. DOI:10.1007/s10902-016-9727-z

52. Atlanta Metropolitan State College. (2020). "Keys to academic success." https://www.atlm.edu/academics/keys-toacademic-success.aspx

53. Celik, I. \& Sarlçam, H. (2018). "The relationships between academic locus of control, positive thinking skills, and grit in 
high school students." Universal Journal of Educational Research 6(3):392-398. DOI:10.13189/ujer.2018.060305

54. Pellerin, R. \& Perrier, N. (2018). "A review of methods, techniques, and tools for project planning and control." https://www.tandfonline.com/doi/abs/10.1080/00207543.2018 .1524168

55. DeVries, H. (2018). "The new rules for the power of positive thinking." https://bit.ly/3rYS7Mn

56. Feldscher, K. (2016). "How the power of positive thinking works."

https://news.harvard.edu/gazette/story/2016/12/optistic-

women-live-longer-are-healthier/

57. Johns Hopkins. (2020). "The power of positive thinking." https://www.hopkinsmedicine.org/health/wellness-andprevention/the-power-of-positive-thinking

58. Croucher, S. Rahmani, D., Sakkinen, K., \& Hample, D. (2016). "Communication apprehension, self-perceived communication competence, and willingness to communicate in Singapore." https://immi.se/intercultural/nr40/croucher.html

59. Diloyan, A. (2017). "The importance of communication in the classroom: The impact of effective communication skills on student enthusiasm." https://baec.aua.am/files/2017/09/Angela_Diloyan_The-

Importance-of-Communication-in-the-

Classroom_Capstone.pdf

60. López-Rocha, S., \& Vailes, F. (2017). "Developing intercultural communicative competence for the Year Abroad experience." In C. Álvarez-Mayo, A. Gallagher-Brett, \& F. Michel (Eds), Innovative language teaching and learning at university: enhancing employability (pp. 67-75). Researchpublishing.net. innoconf2016.656

61. Alhadlaq, I. (2016). "How technology influences communication." International Journal of Scientific \& Engineering Research 7(1), 960-963. http://www.ijser.org

62. Harankhedkar, H. (2011). "Impact of Technology on Communication." http://www.buzzle.com/articles/impact-oftechnology-oncommunication.html

63. Lenhart, A. (2015). "Teens, technology, and friendships: Video games, social media, and mobile phones play an integral role in how teens meet and interact with friends." https://www.pewresearch.org/internet/2015/08/06/teenstechnology-and-friendships/

64. Khan, A., Khan, S., Zia-Ul-Islam, \& Khan, M. (2017). "Communication skills of a teacher and its role in developing the students' Academic success." Journal of Education and Practice 8(1), 18-21.

65. Sng, B. (2012). "The Impact of Teachers' Communication Skills on Teaching: Reflections of Pre-service Teachers on their Communication Strengths and Weaknesses." Humanizing language teaching 14(10). http://old.hltmag.co.uk/feb12/mart.htm

66. Khan, A. \& Khan, S. (2017). "Communication skills of a teacher and its role in developing the student's academic success."

https://www.researchgate.net/publication/315836040_Comm unication_Skills_of_a_Teacher_and_Its_Role_in_the_Develo pment_of_the_Students_Academic_Success
67. Soomro, A. H., Bango, Z. A., \& Mahesar, I. K. (2018). "An Attitudinal study of English as a Foreign language in Sukkur Sindh Pakistan." Journal of Education and Educational Development 5(1), 123-138.

68. Coşkun, G. \& Taşgın, A. (2018). "An investigation of anxiety ang attitudes of university students towards English courses." Journal of Language and Linguistic Studies 14(2), 135-153.

69. Needham, D. (2019). "The importance of language learning." https://www.educations.com/articles-and-advice/theimportance-of-language-learning-14459

70. American Council on the Teaching of Foreign Languages (ACTFL). (2020). "Benefits of language learning."

71. Alizade, M. (2016). "The impact of motivation on English language learning." International Journal of Research in English Education 1(1), 11-15.

72. Bower, K. (2019). "Explaining motivation in language learning: a framework for evaluation ang research." The Language Learning Journal 47(5), 558-574.

73. Karaoglu, S. (2008). "Motivating language learners to succeed." https://www.tesol.org/read-andpublish/journals/other-serial-publications/compleatlinks/compleat-links-volume-5-issue-2-(June-

2008)/motivating-language-learners-to-succeed

74. Marashi, H., Assgar, F. (2019). "EFL teachers' effective classroom management and learners' anxiety and learning strategies." Iranian Journal of Language Teaching Research 7(2), 65-82.

75. Debreli, E., Ishanova, I., \& Sheppard, C. (2019). "Foreign language classroom management: Types of student misbehavior and strategies adopted by the teachers in handling disruptive behavior." Cogent Education 6(1). https://doi.org/10.1080/2331186X.2019.1648629

76. Macias, D. F. (2018). "Classroom management in foreign language education: An exploratory review." Profile: Issues in Teachers' Professional Development, 20(1), 153-166. https://doi.org/10.15446/profile.v20n1.60001.

77. Marmoah, S. \& Denmar, D. (2017). "The analysis of classroom management in teaching English." IOSR Journal Of Humanities And Social Science (IOSR-JHSS), 22(1), 7278 .

78. Yilmaz, E., Şahin, M., \& Turgut, M. (2017). "Variables affecting student motivation based on academic publications." Journal of Education and Practice, 8(12). https://files.eric.ed.gov/fulltext/EJ1140621.pdf

79. Kirmizi, Ö., \& Sarıçoban, A. (2018). "Prospective EFL teachers' locus of control and academic self-efficacy in a Turkish context." Journal of Language and Linguistic Studies, 14(3),

308-324. http://www.jlls.org/index.php/jlls/article/view/986

80. Sundjoto, S. (2017). "The role of Internal locus of control on intrinsic motivation and employee performance of a ceramic company in East Java." IOSR Journal of Business and Management (IOSR-JBM), 19(7), 19-35.

81. Kader, A. (2014). "Locus of control, student motivation, and achievement in principles"

82. Zhang, Y. (2017). "A Study on ESL teachers' intercultural communication competence." English Language Teaching 10(11), 229-235. DOI: 10.5539/elt.v10n11p229

83. Skinner, B. F. (1938). "The behavior of organisms: an experimental analysis." Appleton-Century. New York. 
84. Skinner, B. F. (1948). "Superstition' in the pigeon." Journal of Experimental Psychology, 38, 168-172.

85. Rotter, J. B. (1954). "Social learning and clinical psychology." Prentice-Hall, Inc. https://doi.org/10.1037/10788-000

86. Rotter, J. B. (1966). "Generalized expectancies for internal versus external control of reinforcement." Psychological Monographs: General and Applied. (80), 128. doi:10.1037/h0092976.

87. Habermas, J. (1970). "Towards a theory of communicative competence." Inquiry, 13(1-4), 360-375. https://doi.org/10.1080/00201747008601597 